\title{
Students' Writing Ability In Writing Descriptive Text By Using Mind Mapping Technique (A Classroom Action Research In Class X-A UPW)
}

\author{
${ }^{1}$ Beti Sugiharti, Sudirman, Gede Sukerama \\ ${ }^{1}$ English Language and Education Program \\ Ganesha University of Language and Art Faculty \\ E-mail : Beti.fkipinggris@gmail.com
}

\begin{abstract}
Abstrak
Penelitian ini dilaksanakan untuk meningkatkan kemampuan menulis siswa kelas X-A UPW dalam menulis teks descriptif dengan menggunakan tehnik mind mapping atau peta konsep. Subjek dari penelitian ini adalah kelas X-A UPW SMK Negeri 1 Singaraja yang berjumlah tiga puluh enam siswa. Penelitian ini dilaksanakan berdasarkan pada hasil observasi yang menunjukkan bahwa siswa mempunyai kesulitan dalam menulis, seperti; kesulitan dalam tata bahasa, kurangnya kalimat yang bervariasi, tidak masuk akal dan kosakata yang lemah. Jenis penelitian ini adalah penelitian tindakan kelas dan dilaksanakan dalam dua siklus. Masing-masing siklus terdiri dari rencana, pelaksanaan, observasi dan refleksi. Instrumen yang digunakan dalam penilitian ini adalah tes (pre-tes, post tes 1 , post tes 2 ) dan angket. Hasil dari penelitian ini menunjukkan adanya peningkatan pada kemampuan menulis dan prestasi siswa dalam menulis teks deskriptif dan melewati kriteria ketuntasan minimal (75) pada siklus pertama. Nilai rata-rata meningkat dari 70,77 (pre-tes) menjadi 74,77 (post tes 1) dan 80,5 (pos tes 2). Kesimpulannya adalah peta konsep adalah suatu teknik yang tepat untuk meningkatkan kemampuan siswa dalam menulis teks deskriptif. Sebagai tembahan, penelitian ini menyarankan agar penelitian selanjutnya meneliti bermacam-macam teks menggunakan tehnik peta konsep, seperti teks eksposisi analitis, diskusi dan eksposisi hortatori.
\end{abstract}

Kata kunci : Menulis, Peta Konsep, Teks Deskripsi

\begin{abstract}
This research was conducted to improve the X-A UPW class students' ability in writing descriptive text by using Mind Mapping technique. The subject of this research were the X-A UPW students of SMK Negeri 1 Singaraja which consisted of 36 students. The study was made based on the prelimnary observation which indicated that students had problem in writing, such as; poor organization, gramatically awkward, lack of sentence variety, less of coherence and weak in vocabulary usage. The type of the study was classroom action research and conducted on two cycles. Each cycles divided into planning, action, observation and reflection. The instruments used on this research were tests (pre-test, post test 1, post test 2) and questionnaire. The result of this research showed improvement in students' writing ability and achievement in writing decriptive text and passing standard score (75) on the first cycle. The mean score improved from 70,77 (pre-test) into 74,77 (post test 1) and 80,05 (post test 2). In conclusion, mind mapping is a suitable technique to improve the students' ability in writing descriptive text. Furthermore, this study suggested that further researchers investigate various texts by using Mind Mapping, such as analytical exposition, Discussion or Hortatory Exposition.
\end{abstract}

Key words: Writing, Mind Mapping, Descriptive Text

\section{Introduction}

Writing is one of productive skills besides speaking (Harmer, 2007, p. 275) which should be mastered by students. One of writing texts which should be produced by students in a vocational high school is descriptive text. In writing a descriptive text, students have to describe everything related to the object that will be described.It means that students are 
expected to be able to write descriptive text by developing idea based on their knowledge by describing idea that existed from one paragraph to others. The purpose of descriptive text is to give the audience a description about something. It could be thing, animal, place, etc. Moreover, the generic structure of descriptive text are identification and description. This study focused on investigating students' writing descriptive text about torist destination.

Bowker (2007) stated that writing is a skill that is required in many contexts throughout life. For instance, we can write an email to a friend or reflect on what happened during the day in your personal diary. Writing is not only matter of writing word or sentences, but it is a means of communicating idea to people. Furtermore, Anthony (2007) asserted that writing is a powerful instrument of thinking because it helps students to have control over their thoughts and shapes, their perceptions of themselves, and the world around them. While according to Raimes (1983, p. 3) writing is a skill in which we express ideas, feeling, and thought which are arranged in words, sentences and paragraph using eyes, brain and hands. This also means the writers have to be able to compose and integrate information through components of linguistic logically. They have to develop their own ideas into coherence sentence, cohesively and good organization, e.g., constructing words into phrase, then into clasue, and complete sentence containing certain idea arranged in logical order, so the reader can easily understand the language being used in written language.

In addition, Linse \& Nunan (2006) said that writing is the combination between process and product. The process is when collecting the ideas that can create product which can be read by the readers. So, the students should be able to process their ideas into an understandable product of writing therefore their mesage can be understood by the reader. Moreover, Hedge (1998, p. 159) asserts that writing is the result of employing strategies to manage the composing process, which is one gradually developing text. It involves a number of activities: setting goals, generating idea, organizing information, selecting appropriate language, making a draft, reading and reviewing it, then revising and editing. From the statements, it can be concluded that writing is the complex process to express ideas, feeling and taught in the written form involving several indicators: grammar, vocabulary, content, mechanic and organization as the integral part of indirect communication between the writer and the reader.

After knowing the definition about writing, the writer have to describe what is writing ability. Writing ability is a skill or quality of someone to explore their ideas or concept to communicate it with somebody else through signs or symbols in written form (Ur, 1996). Further, Reichlet (2005, p. 93) states that the ability to write is considered essential as a means of developing, reinforcing, and testing students' target laguage communicative avbilities, grammatical accuracy and the use of vocabulary. It can be said that writing is the communicative process of expressing and sharing idea which requires the ability to write through telling or transform pieces of information in the form of text which requires good vocabulary and grammar mastery.

Heaton (1998,p. 135) states a view that the writing skills are complex and sometimes difficult to tach, requiring mastery not only of grammatical and rethorical devices but also of conceptual and judgement elements. The varied skill are grouped into five feneral components or main areas. They are: language use or the ability to write correct and appropriate sentences, mechanical skills is the ability to use correctly those conventions peculiar to the written language, e.g. punctuation, spelling, treatment of content is the ability to think creatively and develop thoughts, Stylistic skills is the ability to manipulate sentences and pragraphs and use language effectively, last judgement skills is the ability to write in appropriate manner for a particular purpose with a particular audience in mind, together with an ability to select, organize and order relevant information. Concisely, writing ability is the skill to express idea, thought, and feeling to other in writing symbol to make other people or readers understand the idea conveyed.

In conclusion, writing serves many different purposes for different writer. Through writing, ones can share their ideas, knowledge about something, or their opinion about particular things. Realizing about the purpose of writing is very important before a student 
start to write, so they can express their purpose of writing clearly to audience. By following each stage of writing, students are axpected to produce a good and effective writing. Writing has characteristic to be a reference if writing has good quality. There are five characteristics of good writing according to Harmer (2007, p. 19). They are: Organization, content, grammar, vocabulary and mechanic. The first is organization. Writing should contain logical or assosiative connections and transitions which clearly express the relationship of the idea described. It contains ideas, and it is supported by supporting sentences. Mean sentences and supporting sentences should be orgnized well to make readers easy understanding text.

The second is content, it means that a good writing the sentences are easy for readers. Readers can understand the meaning of writing easily. The third is grammar. Grammar is to connect words into good sentences. Writer uses the appropriate tenses to appear meaning clearly. Writing must convey the main idea. The substance of the writer is the ideas expressed. Furthermore, vocabulary. Vocabulary is foundation that should be used by the students while writing process. To have good writing, students have to have enough vocabulary to support their writing. The last is mechanics. Mechanics in writing is including punctuation, spelling and capitalization. Punctuation is symbol to sign sentences, spelling is the way that a particular word is written and capitalization is beginning a word with a capital letter. Good mechanics will make the reader easier to get the messages of the writing.

The five aspect mentioned above would be measurement for students' achievement in writing descriptive text. The objective of writing is to produce a kind of writing text. Based on Curriculum 13 or K-13, students in senior/vocational high school have to be able to not only understand the nature of writing but also to produce certain various short functional texts, monologues and essays in the form of procedure, narrative, descriptive, recount and report text. Moreover, writing can facilitate students for better learning English.This study focused on vocational school students that should be able to write a descriptive text by using mind mapping technique. After knowing what is writing, writing ability and what is the characteristics of good writing, we have to know what is mnd mapping, because in this study it is one of technique that used in investigating students' improvement in writing descriptive text.

A mind map is a diagram used to represent words, ideas, tasks, or other items linked to and arranged around a central key word or idea. Mind maps are used to generate, visualize, structure, and classify ideas, and as an aid in study, organization, problem solving, decision making, and writing. Mind mapping developed by Buzan in 1960s. Some expert it refer to as strategy and another refer to mind mapping as technique. Meanwhile, Hedge (1998) states making a mind map is a strategy for note-making before writing; in other words, scribbling down ideas about a topic and developing those ideas as the mind makes associations (P. 30). So, it can be said that mind mapping can give students a way to begin writing assignments. Hayes (1992) states that through mind mapping students turns random thoughts into patterns that can be written down and developed (p.203). Students become increasingly motivated to complecute a writing task as their ideas emerge in organized forms.

According to Kotob, Styger and Richardson (2016) mind mapping is a technique for delivering effective and creative thinking. The technique helps in arranging and presenting research concepts visually around a central key word or ideas. In the other word, Alamsyah (2009) argued mind mapping is a useful technique that helps you learn more effectively, improves the way that you record information, and supports and enhances creative problem solving. Mind mapping is a good tool to help you write a good structure on focus of essay. Mind mapp help you to appearance all argument picture and to value objectively what argument and structure of essay is rational. Mind mapp not only help you to plan what you want to write, but also useful when you write completely stated that by Buzan (2006).

In this study, the researcher used mind mapping as a technique to improve students' ability in writing descriptive text. Mind mapping is a technique that uses brain management to open all the hidden brain potency and capacity. Buzan (2008) mentions seven stages to 
make a mind mapping are; first the central image has to describe the main idea of a mind mapping. It should be put on the centre of the paper to activate the students' right brain, strengthen tehir memory and make the learning activity enjoyable. By activating the right brain, mind mapping will help the students to get the ideas easily. As a result, their writing would be rich of ideas.

The second is key word. It is a word that can lead a sentence or event. By using key word, the students would be easy to get ideas. Key word mean many things. As a result, it would be developed easily. The third is basic ordering ideas are the branches that collect short information. It is connected to the central topic that radiate out from the centre. By presenting ideas in a radial, graphical, non-linear manner, mind maps encourage a brainstorming approach to organizational tasks. They allow for greater creativity when recording ideas and information, as well as allowing the note-taker associate words with visual representation. This orientation towards brainstorming encourages user users to enumerate and connect concept without a tendency to begin with a particular conceptual framework. The fourth, the elements of mind are arranged intuitively according to the importance of the concept, and are classified into branches or areas, with the goal of representing connection between portions of information. The branches will help the students to distinguish words or ideas. Therefore, they can quickly identify and understand the structire of a subject, the relative importance of individuals' points, and the way in which facts relate to one another.

The fifth is colour. It is very good in memory sign. It involves the right brain in learning for a long-term memory. In addition, it is a great way to reinforcing the structure and context of a map. As a result, it can help the students communicate the message more effectively. The last but not least is picture. It contributes to the context in which the language is being used. In mind mapping activity, the use of picture will engage the students tobe focus on a certain topic provided in it. I addition, it is very interesting for the students. Therefore, they would be motivated to learn. In applying mind mapping technique, teacher needs to know the parts of mind mapping first. The parts are Central image; key words and basic ordering ideas and branches, colour and pictures. Besides, teacher needs to know the function of each part. When the teacher knows each part and its function, teacher will apply this technique easily and succesfully, at the end teacher can help students to write effectively.

According to Joyce (2014), there are several procedures of teaching writing using mind mapping technique that teacher could apply in the class, they are: explaining Mind Mapping technique, the teacher needs to explain about mind mapping using examples and comparing it to regular brainstorming. Brainstorming is an activity with which most people are familiar. The object in brainstorming is to compile as large a list as possible of potential examples for a given topic. That is a great activity to do in a small group with the entire class. The students could make the mind mapping started from the topic in the middle and the proceeds with keywords that branch off the main topic. The second is making choice. The next procedure that the teacher could do is to ask the students to evaluate how they feel about what is on their map. The teacher might ensure about what ideas that they might want to write about. So, the teacher could tell the students to be not included everything that is on the map; thestudents could erase, edit, and revise it as theymove forward.

After the students clearly understand to the ideas that they have put in their map, the teacher could ask them to begin writing. They could use much the same language they have already written down. It makes the task of composition much more manageable and gives them a concrete tool to reference. Students generally move from the mind map activity into the writing process with more enthusiasm and more direction. The last is adapt it. The teacher of writing could use mind mapping based on the level of students she/he met. For example, the students of lower level could use mind map by attracted them with the colors or picture that they could make creatively. By following each step in applying Mind Mapping teachnique, teacher can aplly this technique in teaching writing succesfully. The most important step is to make sure that the students understand how to create the map and teacher needs to adapt this technique depends on the level of the students. While 
descriptive text is one of genre of texts. This text is one of the text that have to be taught to vocational/senior high school. It is hoped that students in vocational/senior high school will communicate each other in oral and written form of communication. Dscriptive text is difficult enough to learn by the students.

Kemendikbud (2017, p. 1) states that descriptive is a type of text which gives description about an object (living or non-living things) such as person, place or thing. There are three things that have to know, they are communicative purposes, generic structure and language features.The first, social function of writing descriptive text is to describe a particular person, place, thing, or animal. Furthermore, the generic structure of descriptive text it consists of two parts. They are identification and description. Identification is the statement that consist of one topic to be describe, while description, it consists of the details description about the object that is identified in identification. Additionally, in descriptive text, it is focuses on specific participant, uses of attributes, declarative sentence, and simple present tense. Attributive process is used to assign the quality of object. Attribute process is used in active clause such as "it has white fur". Identifying process is used in passive clause such as "the white fur is owned by the cat", it uses adjective to modify noun. For example big house, beautiful beach, beautiful girl and etc. It uses linking verbs, because it describes and object and it uses simple present tense,because everythig that is described should be true.

Besides, there are five types of descriptive text namely, describing process, describing an event, describing personality, describing object and describing place. Describing a process is not only to explain how something is accomplished, but also to explain on why it is done and what is needed to complete the process. To describe an event, a writer should be able to memorize and remember what happened in that event. As the example, people is going to write about inspection of Virus at vegetable., she/he has to explain all details related to the event, so that the readers can imagine the real situation and condition perfectly.

While Keraf (2000) mentions in descriptive writing, the writer transfers the the images, the filling that writer experienced to the reader. The writer tries to convey the image, feeling and experience to readers in order the reader can imagine or as if, they are also engaged on it. However, students make clear description in order to make the reader can imagine the object that being decribed such as students describe about their ideas. Kane (2000), retrieved on January 12, 2012 stated that descriptive text is a description about sensory experience, how something looks, sounds, tastes. Mostly it is about visual experience, but description also deals with other kinds of perception. The purpoe of descriptive text is to describe and reveal a particular person, place or thing in details or specific to make the reader be able to visualize the description. Gerot et al in Mursyid states that descriptive text is a kind of text with a purpose to give information. The context of this kind of text is the description of particular thing, animal, person, or others. It can be concluded that descriptive text is used to describe everything, which is seen by writer in detail. Relating to the quotation, through this text, the readers can imagine what being talked about.

\section{Method}

the research was conducted as Classroom Action Research. Classroom action research used to solve a specific classroom or school problem, improve teaching and other educational strategies or make a decision at a specific level (Santrock, 2004). Based on the explanation above, CAR can be used to analyze learning problem and also find its solution.

The subject of this research is class X-A UPW of SMK Negeri 1 Singaraja academic year 2018/2019 with the totl student of 36 as the main participant. It was held on August 2018 using the Kurt Lewin's Action Research on Priyono (2014, p. 25) in several cycles based on the result of each cycle. 
Figure 1: Classroom Action Research model Adopted from Kemmis in Sanjaya, 2014

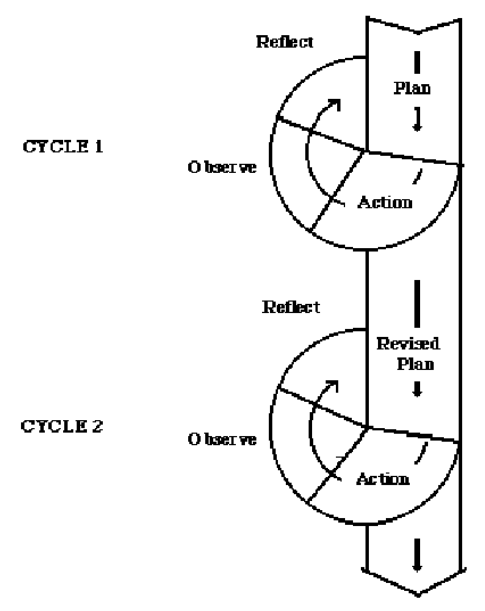

There are four stage in conducting this research using Kemmis's design, they are planning, acting, observing and reflecting as can be seen on Figure 1. Technique of collecting data in this research will use qualitative data and quantitative data. The qualitative data consists of observation. Meanwhile the quantitative data uses pre-test and post-test. Data collection will be be gathered are observation, collaborator's notes and test qhich is shown on Table 1. The instrument used in this study are questionnaire and test (pre-tets and post-test) which consist of content, organization, grammar, vocabulary and mechanic. The calculation of data analysis in finding the mean score use several component, they are mean $(\mathrm{x})$, number of student $(\mathrm{n})$ and individual score $(\mathrm{x})$ using the formula:

$$
\mathrm{X}=\frac{\sum x}{\mathrm{n}}
$$

While in calculating the percentage of passing student, the writer will use three calculation component, they are class percentage $(P)$, total percentage score $(F)$ and number of students $(n)$ with formula:

$$
P=\frac{F x}{n} \times 100 \%
$$

The calculating of students improvement will be conducted using students' improvement $(P)$, pre-test result $(\mathrm{y})$ and post-test result $(\mathrm{y} 1)$ using formula:

$$
P=\frac{\mathrm{y} 1-\mathrm{y}}{\mathrm{Y}} \times 100 \%
$$

In writing assessment, the writer uses writing rubric by Harmer. The scoring rubric focuses on several main aspects such as content, organization, grammar, vocabulary and mechanics. In this study the research will succed if $75 \%$ of students can achieve the target score (KKM) with the target score of 75 . The scoring is started from the pre-test until the post-test in every cycle. Moreover, Classroom Action Research will be fail if the students do not achieve the criteria, and it will be continued in the next cycle. The hypotesis of this research are divide into two, the $\mathrm{Ho}$ and $\mathrm{Hi}$. The hypothesis can be concluded as:

Ho : If the Mind Mapping technique can not improve the writing ability

$\mathrm{Hi} \quad$ : If the Mind Mapping technique can improve the writing ability 
This part will concern with the description of the data in every stage, and consists the findings before implementing the Classroom Action research, and findings after implementing the Classroom Action Research. Before implementing Classroom Action Research, the writer conducted observation on August 2018 in several classes. From this observation, the writer found that the student class X-A UPW was lowest in writing where the overall learning activities was only dominated by certain students. Their problem in writing was clearly shown during writing action in every material. The students were not only having problem to produce a text, but also in writing expression to. Based on the result of pre-test, the data showed that the mean score of the pre-test in X-A UPW is 70,77. From 36 students, only 12 students or $33,33 \%$ of them who can achieve the KKM or 75, while another 24 students or $66,66 \%$ were failed during the pre-test ection. From the pre-test result, itcould be seecn that the students' writing ability was still low compared with KKM.

The implementation of the Classroom action Research in this study consists of cycle 1 and cycle 2. Each cycle was divided into four sections starting from planning, acting, observing and the last is reflecting. A new cycle was made if the conducted cycle did not achieve target. The action of the first cycle was conducted on September 27th, 2018. In the section the writer applied the overall lesson plan which had been created on the previous stage. In this section,the writer also cnducted post tesct for cycle 1. In this stage, the writer plans the action that would be applied on the classroom. The action was made based on the actual problem as the result of the pre-test which had been conducted before. The writer arrange lesson plan based on the basic competence and teaching material. Then, the teacher showed a slide about some tourist destination in Indonesia and asked them about what do they think about the picture. Then various adjective used by students to answer the teacher question. After the teacher asked some questions about the pictures to the students, the teacher asked students about tourist destination that had been visited.

Then the teacher asked a student to describe about the tourist destination that had been visited. In the section, the teacher also make a mind mapping on the whiteboard based on the description of a student that tell the tourist destination. The writer asked them to write a desribe about a tourist destination that they know in fourty minutes at the last hour in English class. After that, the writer collected students' descriptive text. In this stage the writer conducted observation after the overall activities in the classroom. The observation focused on the students' descriptive text using Mind Mapping teachnique. During the stages, it can be seen that not all og them students showed attention to teacher's explanation and instruction. During the practice section several students were still not actively involve in the writing class. In this stage, the writer make conclusion of the overall stages. With the KKM of 75 , it can be seen that the students' writing ability showed positive progress. There were 10 students or $27,77 \%$ of the students who failed to achieve minimum score. The cycle II was conducted on October 4th, 2018. In the section, the writer applied the modified lesson plan which had been created on the previous stage. First, the teacher played the video which contained decriptive material related to adjective that usually used in writing descriptive text. They also work in pair to make them easier in writing the text. Besides, they also can do sharing if they get the difficulties in writing descriptive text.

The test was designed in a writing test activity. To keep on their authentically writing each student should finished their test at the time (not take home) and the writer asked student to attach their mind mapping pattern in the paper next to the descriptive text. The mind mapping consisted of the structure of descriptive itself; identification and description. In identification part it should be consist of definition and location. However in description part it should be consist of the transportation to get there, the cost if it should be taken by public transportation, the facilities that served in the destination, the ticket and the price itself. Moreover, the student should write the activity that can be do there, the condition/situation about the around/weather and the last for whom the destination enjoyed. Those are the mind mapping pattern that should be existed in the text in order to make them easier to develop their idea in writing descriptive text. 
Furthermore, the aspects that became the measurement in scoring students' writing descriptive text with their percentage are; content $(30 \%)$, organization $(20 \%)$, grammar $(20 \%)$, vocabulary $(20 \%)$, and mechanic $(10 \%)$. Unlike the previous cycle, on cycle II, 32 students (90\%) could achieve 75 as the minimum passing score. The writer found positive progress on students' writing descriptive text even though several students were still paying attention to the teacher explanation. Consequently, their writing descriptive text was not in positive progress. Related to the analysis of the data about the results of the students' achievement in pre-test, post test 1 and 2, it shown the increasing of the achievement. It can bee seen clearly in the following chart.

Graph 1 The Improvement in Writing Test

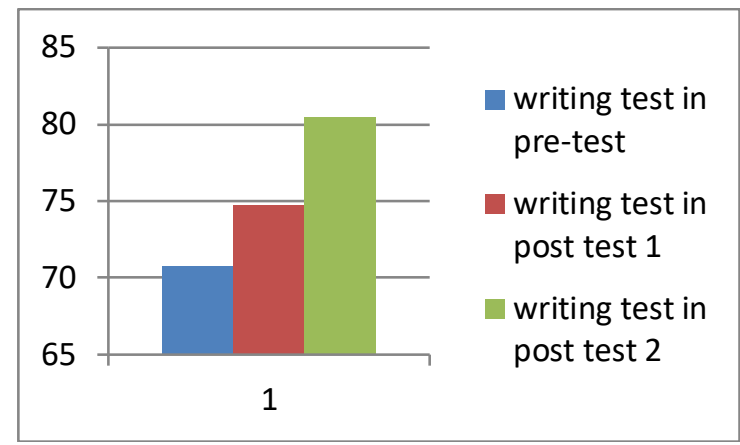

The imrovement of the students in the pre-test, cycle I and cycle II was depicted clearly in thegraph. The students' mean score in the pre-test was 70,77 which could be categorized as "Sufficient". After applying the action of mind mapping technique technique, the students' mean score in writing test was 74,77 which could be categorized "sufficient" in cycle 1. The action was continued to cycle II since the students' score did not reach the succes indicator (75),. The students mean score in cycle II was 80,50 which categorized as "good".

These improvement were interpreted as the result of the psychological and academic factors during the action the psychological factors involved the students' attitude during teaching and learning process, and the students' motivation when joing English writing class. The academic factors involved the nature of Mind Mapping technique that could facilitate the students in writing text. This technique could attract the students to learng writing and it gave more chances to share their knowledge with partner before share with the group. From the psychological factors, it was known that there were changes in the students' attitude during teaching and learning process. The students were more motivated to write. This could be seen from the students' responses in the questionnaire that had been administered in pre-test, post test I and post test II.

Generally, the students showed positive attitude toward the application of Mind Mapping technique. This was indicated from the students' responses in pre-test, post test cycle I and post test cycle II. It couldbe seen from the mean score of the questioonaire pretest was 29 so the criteria was neutral. It could be concluded that the students had problems in writing class. It made the researcher try to apply Mind Mapping technique in ordere to make the students responses be positive. And the result of the questionnaire in cycle 1 was 36 it could be categorized as a neutral responses. In the other hand,the mean score of questionnaire in cycle 2 was 43 and it could be categorized as "positive" responses.

Besides the result of questionnaire, the diary also showed that there were changes in the students' attitude during the teaching and learning process. From finding in cycle I, the researcher made some modifications in the activities of cycle II in the form of pair group. The group was aimed to give them change to discuss and to confirm ideas after writing the text. in this activity, the researcher gave some point that has put down in their mind mapping. The researcher asked the students to develop the point from their friend. Brcause of that, they 
became more active and they could discuss their ideas with their partner, so the idea or mind mapping could be easy to develope and to write.

In terms of the academic factors, the students' improvement was closely related to Mind Mapping technique's nature for facilitating the student in writing descriptive text. Dealing with the nature of Mind Mapping teachnique, the students' responses were generally positive, in which most students thought that Mind Mapping technique could really useful in helping them in writing.

\section{Conclusion}

After the implementation of Classroom Action Research, the writer will explain several conclusions related to the result of the action. The writer will also give suggestions to make the more effective learning process using Mind Mapping technique. The conducted researc is Classroom Action Reseacrh (CAR) which is made in purpose to improve students' writing ability in writing descriptive text of the SMK Negeri 1 Sigaraja. The research was conducted on grade X A UPW of SMK Negeri 1 Singaraja with 36 of total observed student. In this research the writer implemented the theory which consist of four phases starting from planning, actiong, observing and reflecting. The data which is sed during the research is collected using test and questionnaire sheets. On the firest cycle, the mean score had improve from 70,77 to 74,77 . At the end of cycle 2 , the same phenomenon also happened. The mean score of the class had improved into 80,05 (compared with 70,77 on the pre-test and 74,77 on the first cycle. In this cycle, $90 \%$ of students also achieved the minimum score of 75 and successfully passed.

In this part, the writer would like to give some suggestions to be considered by English teacher. First, Mind mapping technique would be very helpful to improve students' skill in writing, so the teacher needs to use this Mind Mapping technique of the teaching. Second, in conducting the classroom activity using Mind Mapping technique, the teacher should give clear explanation and instruction during the classroom activity. Furthermore, in conducting classroom activity and apllying Mind Mapping technique the teacher would be better using various colours when making mind mapping. It would be grab students attention and their motivation in writing text. The last butnot least, the teacher should actively control the students' activities during the learning process.

\section{References}

Bowker, Natilene. 2007. Academic Writing: A Guide to Tertiary Level Writing. Massey university

Brown, H. (2001). Teaching by Principles. Longman: Pearson Education Limited.

Buzan, Tony. 2006.Mind Map Untuk Meningkatkan Kreativitas. Jakarta: Gramedia. Pustaka Utama

Depdiknas, 2004. Standar Kompetensi Mata Pelajaran Bahasa Inggris Sekolah Menengah Atas/Sekolah Menengah Kejuruan .Jakarta: Depdiknas

Hayes, David A. 1992. A Sourcebook of interactive Methods for teaching with text. United States of America.

Harmer, J. (2007). The Practice of English Language Teaching. Pearson. Longman

Heaton, JB. (1998). Writing English Language Test. New York: Edinburg Gate

Hensley, Ben \&Hamp, Liz.(1996). Study Writing.England :Cambridge University Press 
Joyce, B. (2014). How to Use Mind Maps in Your EFL Classroom. Retrieved 26th December 2015 from http://busyteacher.org/4650-how-to-teach-writing-6-methods-forgenerating.html

Keraf, G. (2000). Eksposisi dan Deskripsi, Jakarta: Gramedia

McKay, P. (2006). Assessing Young Language Learners. Cambridge University Press

Nugrahini, Y. (2013). Improving Students' Writing ability of Descriptive Paragraph Through Mind Mapping in Writing Class at STKIP PGRI Tulung Agung in Academic Year 2012/2013

Nurlaila, A. (2013). The Use of Mind Mapping Technique In Writing Descriptive Text. Journal of English and Education, 1(2), p 9-13

Pipih, n. (2013). Teaching Writing Descriptive Text Using Mind Mapping Technique at The Seventh Grade Students' of MTSNegeri Sukasari (in Academic Years 2012-2013)

Raimes, A. (1983). Techniques in Teaching Writing. New York: Oxford University Press. Retrieved 23nd December 2015 from https//Enjoymysite.files.wordpress.com

Riswanto \& Putra. (2012). The Use of Mind Mapping Strategy in Teaching Writing at SMAN 3 Bengkulu, Indonesia. International Journal Humanitis and Social Science. (2)

Rofi'i, A., Rukmini. D Hartono, R. (2014). Improving Students' Motivation in Writing Descriptive Text by Using The Mind Mapping Technique. English ed. Journal. (2)

Sanders, L. (2004). Paragraph Writing: Improving Paragraph Writing Through PLEASE Strategy. Retrieved 21st March 2010 from http://www.curry.edschool.virginia.edu/sped/projects/05/information/ints/para.html

Sudrajat, A. (2008). Lesson Study untuk Meningkatkan Proses dan Hasil Pembelajaran. Retrieved on September $20^{\text {th }}$, 2018 from http://akhmadsudrajat.wordpress.com 